\title{
Beta-globin gene cluster haplotypes in Venezuelan sickle cell patients from the State of Aragua
}

\author{
Nancy Moreno ${ }^{1}$, José A. Martínez ${ }^{2}$, Zorella Blanco ${ }^{3}$, Leidys Osorio ${ }^{1}$ and Patrick Hackshaw ${ }^{4}$ \\ ${ }^{1}$ Laboratorio de Biología Molecular, Universidad de Carabobo Núcleo Aragua. \\ ${ }^{2}$ Departamento de Biología, Universidad Pedagógica Experimental Libertador Maracay, Estado Aragua. \\ ${ }^{3}$ Hospital Dr. Domingo Luciani El Llanito. \\ ${ }^{4}$ Servicio de Hematología del Hospital Central de Maracay, Estado Aragua.
}

\begin{abstract}
Seven polymorphic sites in the $\beta$-globin gene cluster were analyzed on a sample of 96 chromosomes of Venezuelan sickle cell patients from the State of Aragua. The Benin haplotype was predominant with a frequency of 0.479 , followed by the Bantu haplotype (0.406); a minority of cases with other haplotypes was also identified: atypical Bantu A2 (0.042), Senegal (0.031), atypical Bantu A7 (0.021) and Saudi Arabia/Indian (0.021) haplotypes; however, the Cameroon haplotype was not identified in this study. Our results are in agreement with the historical records that establish Sudanese and Bantu origins for the African slaves brought into Venezuela.
\end{abstract}

Key words: haplotypes, Beta-globin gene cluster, sickle cell.

Received: March 5, 2002; accepted: March 25, 2002

\section{Introduction}

Sickle cell disease (SCD) exhibits a wide spectrum of clinical behavior: everything from a mild condition to an incapacitating illness; its hematological characteristics, as well as its clinical severity, are influenced by variations in fetal hemoglobin (HbF) levels (Falusi and Olatungi, 1994; Steinberg, 1996), the simultaneous presence of $\alpha$-thalassemia (Figueiredo et al., 1996; Mukherjee et al., 1997) glucose-6- phosphate dehydrogenase deficiency (Bouanga et al., 1998) and the $\beta$-globin cluster linked haplotypes (Powars and Hiti, 1993; Powars et al., 1994; Steinberg, 1996). The $\beta^{\mathrm{S}}$ gene is in linkage disequilibrium with five main different haplotypes of the $\beta$ gene cluster, which were named according to the geographical areas where they are most prevalent: Benin, Cameroon, Central African Republic (CAR or Bantu), Senegal and Saudi Arabia/Indian (SAI) (Pagnier et al., 1984; Kulozik et al., 1986; Lapouméroulie et al., 1992).

Sickle cell disease was introduced into the American continent mainly by the massive trade of African slaves which occurred between the sixteenth and nineteenth centuries, and is the most common hereditary disorder in the Americas. Sickle cell epidemiological studies carried out in

Send correspondence to Nancy Moreno. Apartado Postal 237, Maracay, Estado Aragua 2101, Venezuela. E-mail: nanmorja@ telcel. net.ve.
Venezuela demonstrated a variable frequency, ranging from zero in the Venezuelan Indians up to 5 percent in the Mestizo and Afro-American populations; in some regions such as the North Central Coastal Region the frequency has risen to as much as 12\% (Arends, 1971; Arends et al., 1982). In order to provide the required information for further analysis of the heterogeneity of the hematological parameters and clinical manifestations of SCD in Venezuela, the DNA $\beta$-globin gene cluster haplotypes were analyzed in 48 Venezuelan sickle cell patients from the State of Aragua. The results were compared with those found in other studies with Venezuelan patients (Arends et al., 2000), Guadeloupe Island (Kéclard et al., 1996) and Iberoamerican populations of Cuba (Muniz et al., 1995), Colombia (Cuellar-Ambrosi et al., 2000) and Brazil (Zago et al., 1992; Figueiredo et al., 1994; Gonçalves et al., 1994; Pante de Sousa et al., 1998, 1999).

\section{Subjects and Methods}

The patient sample was composed of 48 non-related $\mathrm{HbS}$ homozygotes, from the State of Aragua, which is in the North Central Coastal Region of Venezuela, at about $9^{\circ} 23^{\prime}$ to $10^{\circ} 33^{\prime} \mathrm{N}$. and $66^{\circ} 33^{\prime}$ to $67^{\circ} 53^{\prime} \mathrm{W}$. The population of this State is the result of an intense process of admixture among Caucasians, Amerindians, and Afro-Americans and its total population size, according to the 1990 census (OCEI, 1990) represents $6.2 \%$ of the Venezuelan 
population. These patients were attended at the Hematological Service at the Maracay Central Hospital in the State of Aragua. There were 23 males and 25 females, with a mean age of $21 \pm 3.3$ years.

Venous blood samples were collected using EDTA as an anticoagulant, and the hematological parameters were determined by standard laboratory procedures. The buffy coat was used for the preparation of nuclear DNA according to previously described methods (Kirby, 1992). Diagnosis of SCD was based on the Bsu36I digestion of a PCR amplified 536 bp., verifying whether the $\beta$-globin DNA segment contained the $\beta^{\mathrm{S}}$ mutation, as reported previously (Martínez et al., 1998). Haplotypes were determined by the analysis of the following polymorphic restriction sites in the $\beta$-globin gene cluster: 1$) \mathrm{Hinc}$ II 5' of $\varepsilon ; 2) \mathrm{X} m n$ I 5' of $\mathrm{G} \gamma$; 3) Hind III in the IVSII of G $\gamma$; 4) Hind III in the IVSII of A $\gamma$; 5) Hinc II in the $\Psi \beta$; 6) Hinc II 3' of $\Psi \beta$; and 7) Hinf I 5 ' $\beta$. Segments containing each of these sites were amplified by PCR and subsequently digested with the appropriate enzyme. The oligonucleotide primers used for the analysis of sites 2 to 7 were described by Sutton et al. (1989) and site 1 was analyzed using a primer reported by Guerreiro et al. (1992).

\section{Results}

The $\beta$-globin cluster haplotypes identified in the Venezuelan patients are presented in Table I. Benin is the most frequent with a frequency of 0.479 , followed by Bantu (0.406), Senegal (0.031), and Saudi Arabia/Indian (0.021). The Bantu A2 and Bantu A7 atypical haplotypes described by Srinivas et al. (1988) were observed with a frequency of 0.042 and 0.021 , respectively. No Cameroon haplotypes were identified in this study. Fourteen of the 48 SCD patients were homozygous for the Benin haplotype (29.2\%), 9 were Bantu homozygotes (18.7\%) and all the others were
Table I - $\beta$-globin gene cluster haplotypes identified in a sample of 96 chromosomes from Venezuelan sickle cell patients

\begin{tabular}{lcc}
\hline Haplotype & $\begin{array}{c}\text { Number of } \\
\text { chromosomes }(\mathrm{n}=96)\end{array}$ & Frequency \\
\hline Benin & 46 & 0.479 \\
Bantu & 39 & 0.406 \\
Atypical Bantu A2 & 4 & 0.042 \\
Senegal & 3 & 0.031 \\
Saudi Arabia/Indian & 2 & 0.021 \\
Atypical Bantu A7 & 2 & 0.021 \\
\hline
\end{tabular}

heterozygotes $(52.1 \%)$. Table II shows the $\beta^{\mathrm{S}}$ typical haplotype frequency distribution among the Venezuelan patients studied in this work, compared with those from several Iberoamerican populations and Caribbean Islands.

\section{Discussion}

The data reported in this study indicated that the Benin (47.9\%) and Bantu (40.6\%) haplotypes were the most prevalent, Senegal was present in $3.1 \%$ of the patients, a value similar to that found in the western region of $\mathrm{Co}-$ lombia (4.3\%) and the Belém population of Brazil (3.4\%). The frequencies of the two atypical haplotypes, Bantu A2 (4.2\%) and Bantu A7 (2.1\%), are some of the highest reported in American populations. This observation can be interpreted as resulting from of recombinatorial events involving the Bantu typical haplotype and the 5' regions from various haplotypes present in normal individuals as described by Srinivas et al. (1988). In an admixed population such as the Venezuelan, there are more probabilities of observing these events.

Fifty-two percent of the SCD patients studied presented heterozygous haplotypes, as was expected due to the

Table II - Frequency distribution (\%) of the typical $\beta^{\mathrm{S}}$ haplotypes in patients from Iberoamerican populations and the Guadeloupe Island.

\begin{tabular}{|c|c|c|c|c|c|c|}
\hline \multirow[t]{2}{*}{ Population } & \multirow[t]{2}{*}{ N. of chromosomes } & \multicolumn{5}{|c|}{ Haplotypes } \\
\hline & & Bantu & Benin & Senegal & Arab/Indian & Cameroon \\
\hline Venezuela (State Aragua) ${ }^{1}$ & 90 & 43.3 & 51.1 & 3.3 & 2.2 & 0.0 \\
\hline Venezuela (All country) ${ }^{2}$ & 176 & 32.4 & 51.1 & 14.2 & 0.0 & 2.3 \\
\hline $\mathrm{Cuba}^{3}$ & 198 & 41.0 & 51.0 & 8.0 & 0.0 & 0.0 \\
\hline Colombia (Western Region) ${ }^{4}$ & 92 & 55.5 & 34.8 & 4.3 & 0.0 & 5.4 \\
\hline Brazil (Afro-Brazilians from the Amazon Region) ${ }^{5}$ & 20 & 60.0 & 10.0 & 30.0 & 0.0 & 0.0 \\
\hline Brazil (Belém, State of Pará) ${ }^{6,7}$ & 59 & 66.1 & 30.5 & 3.4 & 0.0 & 0.0 \\
\hline Brazil (Salvador, State of Bahia) ${ }^{7}$ & 42 & 55.0 & 45.0 & 0.0 & 0.0 & 0.0 \\
\hline Brazil (Ribeirão Preto, State of São Paulo) ${ }^{7,8}$ & 67 & 73.0 & 25.5 & 1.5 & 0.0 & 0.0 \\
\hline Brazil (Campinas, São Paulo) ${ }^{9}$ & 142 & 79.6 & 18.4 & 2.0 & 0.0 & 0.0 \\
\hline Guadeloupe $^{10}$ & 252 & 11.5 & 77.0 & 8.7 & 0.0 & 2.8 \\
\hline
\end{tabular}

${ }^{1}$ Present study; ${ }^{2}$ Arends et al. (2002); ${ }^{3}$ Muniz et al. (1995); ${ }^{4}$ Cuellar-Ambrosi et al.(2000); ${ }^{5}$ Pante de Sousa et al. (1999); ${ }^{6}$ Pante de Sousa et al. (1998); ${ }^{7}$ Figueiredo et al. (1994); ${ }^{8}$ Zago et al. (1992); ${ }^{9}$ Gonçalves et al. (1994). ${ }^{10}$ Kéclard et al. (1996). 
admixture process which occurs in our population; in a study carried out on African SCD patients, the vast majority of haplotypes were found in homozygosity (Sow et al., 1995). Our results differed significantly from those reported by Arends et al. (2000) in another study performed on sickle cell Venezuelan patients from all over the country $\left(\chi^{2}=14.62\right.$; d.f. $\left.=4 ; p<0.01\right)$. This may be due to different patient ascertainment and/or a diverse historical origin of the African-derived patients from Aragua. On the other hand, our results are in agreement with the haplotype distribution found in patients from Cuba $\left(\chi^{2}=6.60\right.$; d.f. $=3$; $\mathrm{p}>0.05)$; while significant differences exist with the Colombian data $\left(\chi^{2}=11.23\right.$; d.f. $\left.=4 ; \mathrm{p}<0.025\right)$. A highly significant difference was observed when the Venezuelan patients were compared with those from Guadeloupe $\left(\chi^{2}=42.63\right.$ d.f. $\left.=2 ; \mathrm{p}<0.001\right)$, and those from Brazil $\left(\chi^{2}=20.03\right.$; d.f. $\left.=3 ; p<0.001\right)$. It is probable that all these differences reflect the origin of the forced migration of African slaves to the American continent, although, as was indicated for the two Venezuelan samples, patient ascertainment should also be considered.

African slavery was instituted in Venezuela to meet the growing labor demands of an emerging agricultural economy; historically it is reported that the African slaves brought to Venezuela were from the Sudan and Bantu regions (Acosta Saignes, 1984), although some slaves came to Venezuela from the others colonies, especially the Antilles; in consequence, the predominance of the Benin and Bantu haplotypes is in accordance with these historical records.

\section{Acknowledgments}

We are grateful to the blood donors for their collaboration with this investigation. We offer special thanks to Mrs Melanie Mackie and Lic. Jesús Ernesto Lisboa M. for their contribution in the manuscript revision. This research was supported by BID-CONICIT Grant BTS-067, CDCH Universidad de Carabobo Grant 90-007 and CIADANA.

\section{References}

Acosta Saignes M (1984) Vida de los esclavos negros en Venezuela. Editorial Vadell Hermanos, Caracas.

Arends A, Alvarez M,Velázquez D, Bravo M, Salazar R, Guevara JM and Castillo O (2000) Determination of $\beta$-globin gene cluster haplotypes and prevalence of $\alpha$-thalassemia in sickle cell anemia patients in Venezuela. Am. J. Hematol. 64:87-90.

Arends T (1971) Epidemiology of hemoglobin variants in Venezuela. In: Genetical, Functional, and Physical Studies of Hemoglobins. Arends T, Bemsky G and Nagel RL (eds) S. Karger, Basel, pp. 82-98.

Arends T, Garlin G, Perez-Bandes O and Anchustegui M (1982) Hemoglobin variants in Venezuela. Hemoglobin 6:243-246.

Bouanga JC, Mouele R, Prehu C, Wajcman H, Feingold J and Galacteros F (1998) Glucose-6-phosphate dehydrogenase deficiency and homozygous sickle disease in Congo. Hum. Hered. 48:192-197.

Cuellar-Ambrosi F, Mondragon MC, Figueroa M, Prehu C, Galacteros F and Ruiz-Linares A (2000) Sickle cell anemia and $\beta$-globin gene cluster haplotypes in Colombia. Hemoglobin 24:221-225.

Falusi AG and Olatungi PO (1994) Effects of alpha thalassaemia and haemoglobin $\mathrm{F}(\mathrm{HbF})$ level on the clinical severity of sickle-cell anaemia. Eur. J. Haematol. 52:13-15.

Figueiredo MS, Silva MCBO, Guerreiro JF, Souza GP, Pires ACR and Zago MA (1994) The heterogeneity of the $\beta^{S}$ cluster haplotypes in Brazil. Gene Geogr. 8:7-12.

Figueiredo MS, Kerbauy J, Gonçalves MS, Arruda VR, Saad ST, Sonati MF, Stoming T and Costa FF (1996) Effect of alpha-thalassemia and beta-globin gene cluster haplotypes on the hematological and clinical features of sickle-cell anemia in Brazil. Am. J. Hematol. 53:72-76.

Gonçalves MS, Nechtman JF, Figueiredo MS, Kerbauy J, Arruda VR, Sonati MF, Saad SO, Costa FF and Stoming TA (1994) Sickle cell disease in a Brazilian population from Sao Paulo: a study of the beta S haplotypes. Hum. Hered. 44:322-327.

Guerreiro JF, Figueiredo MS, Santos SEB and Zago MA (1992) $\beta$-globin gene cluster haplotypes in Yanomama Indians from the Amazon region of Brazil. Hum. Genet. 89:626-631.

Kéclard L, Ollendorf V, Berchel C, Loret H and Mérault G (1996) $\beta^{S}$ haplotypes, $\alpha$-globin gene status, and hematological data of sickle cell disease patients in Guadeloupe (F.W.I.). Hemoglobin 20:63-74.

Kirby L (1992) DNA extraction. In: DNA Fingerprinting. W.H. Freeman and Company, New York, pp. 55-70.

Kulozik AE, Wainscoat JS, Serjeant GR, Kar BC, Al-Awamy B, Essan GJF, Falusi AG, Hague SK, Hilali AM, Kate S, Ranasinghe WACP and Weatherall DJ (1986) Geographical survey of $\beta$-globin gene haplotypes: evidence for an independent Asian origin of the sickle cell mutation. Am. J. Hum. Genet. 39:239-244.

Lapouméroulie C, Dunda O, Ducrocq R, Trabuchet G, Mony-Lobe M, Bodo JM, Carnevale P, Labie D, Ellion J and Krishnamoorthy R (1992) A novel sickle gene of yet another origin in Africa: the Cameroon type. Hum. Genet. 89:333-337.

Martínez J, Blanco Z, Hakcshaw P and Moreno N (1998) Aplicación de la reacción en cadena de la polimerasa (PCR) en el diagnóstico de la anemia falciforme en Venezuela. Sangre 43:63-66.

Mukherjee MB, Lu CY, Ducrocq R, Gangakhedkar RR, Colah RB, Kadam MD, Mohanty D, Nagel RL and Krishnamoorthy R (1997) Effect of alpha-thalassemia on sickle-cell anemia linked to the Arab-Indian haplotype in India. Am. J. Hematol. 55:104-109.

Muniz A, Corral L, Alaez C, Svarch E, Espinosa E, Carbonell N, Di Leo R, Felicetti L, Nagel RL and Martinez G (1995) Sickle cell anemia and $\beta$-gene cluster haplotypes in Cuba. Am. J. Hematol. 49:163-164.

Oficina Central de Estadística e Informática (1990) XII Censo General de Población y Vivienda. Caracas, Venezuela.

Pagnier J, Mears JG, Belkhodja OD, Schaefer-Rego KE, Beldjord C, Nagel RL, and Labie D (1984) Evidence for the multicentric origin of the sickle cell hemoglobin gene in Africa. Proc. Natl. Acad. Sci. USA 81:1771-1773. 
Pante de Sousa G, Mousinho-Ribeiro RC, Santos EJM, Zago MA and Guerreiro JF (1998) Origin of the hemoglobin S in a northern Brazilian population: the combined effects of slave trade and internal migrations. Genet. Mol. Biol. 21:427-430.

Pante de Sousa G, Mousinho-Ribeiro RC, Melo dos Santos EJ and Guerreiro JF (1999) $\beta$-globin haplotypes analysis in Afro-Brazilians from the Amazon region: evidence for a significant gene flow from Atlantic West Africa. Ann. Hum. Biol. 26:365-373.

Powars D and Hiti A (1993). $\beta^{\text {s }}$ gene cluster haplotypes as genetic markers for severe disease expression. Am. J. Dis. Child. 147:1197-1202.

Powars DR, Meiselman HJ, Fisher TC, Hiti, A and Johnson C (1994) Beta-S gene cluster haplotypes modulate hematologic and hemorheologic expression in sickle cell anemia. Use in predicting clinical severity. Am. J. Pediatr. Hematol. Oncol. 16:55-61.
Sow A, Peterson E, Josifovska O, Fabry ME, Krishnamoorthy R and Nagel RL (1995) Linkage-disequilibrium of Senegal haplotype with the $\beta^{\mathrm{S}}$ gene in the Republic of Guinea. Am. J. Hematol. 50:301-303.

Srinivas R, Dunda O, Krishnamoorthy R, Fabry ME, Georges A, Labie D and Nagel RL (1988) Atypical haplotypes linked to the $\beta^{\mathrm{S}}$ gene in Africa are likely to be the product of recombination. Am. J. Hematol. 29:60-62.

Steinberg, MH (1996) Modulation of the phenotypic diversity of sickle cell anemia. Hemoglobin 20:1-19.

Sutton M, Bouhassira EE and Nagel RL (1989) Polymerase chain reaction amplification applied to the determination of $\beta$-like globin gene cluster haplotypes. Am. J. Hematol. 132:66-69.

Zago MA, Figueiredo MS and Ogo SH (1992) Bantu $\beta^{\mathrm{S}}$ cluster haplotype predominates among Brazilian blacks. Am. J. Phys. Anthropol. 88:295-298. 